\title{
EXPOSING THE WHORE: MISOGYNY IN PROSTITUTE NARRATIVES OF RESTORATION ENGLAND*
}

\author{
Jorge Figueroa Dorrego \\ Universidade de Vigo
}

\section{Abstract}

Although the prostitute became a fairly common figure in eighteenth-century prose fiction, there were already narrative texts dealing with that type of character in Restoration England, although most of them have been largely disregarded. This article will focus on three of those texts: 1) The Crafty Whore (1658), an anonymous dialogue between two courtesans that is framed between a preface that presents it as a cautionary text, and an epilogue entitled "Dehortation from Lust"; 2) Richard Head's The Miss Display'd (1675), a narrative in the picaresque mode introduced by an admonitory preface and told by an intrusive third-person narrator that is often critical of prostitutes and women in general; and 3) the anonymous The London Jilt (1683), another picaresque novel presented as a cautionary tale to warn readers against the deceit and corruption of prostitutes, but with an autodiegetic narrator who interlaces the relation with social and moral comments. In these texts the female agency and voice are often curbed by a male authorial voice that uses a misogynistic discourse in an alleged attempt to expose the crafty contrivances of prostitutes in order to ensnare men. KeYwORDs: prostitute narratives, Restoration England, misogyny, The Crafty Whore, The Miss Display'd, The London Jilt.

\section{REVELANDO A LA RAMERA: MISOGINIA EN NARRACIONES SOBRE PROSTITUTAS DE LA INGLATERRA DE LA RESTAURACIÓN}

\section{RESUMEN}

Aunque la prostituta es un personaje frecuente en la novela inglesa del siglo XviII, ya aparece en textos narrativos publicados en la Inglaterra de la Restauración, aunque la mayoría de ellos han sido ignorados. Este artículo analiza tres de esos textos: 1) The Crafty Whore (1658), un diálogo anónimo entre dos cortesanas que está enmarcado entre un prefacio que lo presenta como una advertencia, y un epílogo titulado «Disuasión de la lujuria»; 2) The Miss Display'd de Richard Head (1675), una novela en modo picaresco introducida por un prefacio también admonitorio y relatada por un narrador intruso en tercera persona que es a menudo crítico con las prostitutas y las mujeres en general: y 3) la anónima The London Jilt (1683), otra novela picaresca presentada como relato que alerta a los lectores contra el engaño y la corrupción de las prostitutas, pero con un narrador autodiegético que entrelaza la narración con comentarios de tipo social y moral. En estos textos la voz y agencia femenina se ven refrenadas por una voz autorial masculina que utiliza un discurso misógino con la intención de revelar los astutos ardides de las prostitutas con el fin de engañar a los hombres. PALABRAS CLAVE: narraciones sobre prostitutas, Inglaterra de la Restauración, misoginia, The Crafty Whore, The Miss Display'd, The London Jilt.

DOI: https://doi.org/10.25145/j.recaesin.2019.79.03 


\section{INTRODUCTION}

The prostitute is a fairly common figure in eighteenth-century prose fiction, featuring in well-known novels written by authors such as Daniel Defoe, Eliza Haywood, Henry Fielding, Samuel Richardson and John Cleland, for instance. However, there were a considerable number of narrative texts dealing with that type of character already in seventeenth-century England, although most of them have been largely disregarded by scholars so far. Among these texts, the following can be mentioned: The Crafty Whore: or, The Mystery and Iniquity of Bawdy Houses Laid Open (1658), The Practical Part of Love (1660), The Wandring Whore (1660), Strange Newes from Bartholomew Fair, or, The Wandring-Whore Discovered (1661), Richard Head's The Miss Display'd (1675), The London Jilt: or, The Politick Whore (1683), and The Whore's Rhetorick (1683). These prose fiction works, together with the publication of a large amount of pamphlets, satirical poems, character sketches, periodical essays, and other forms of what may be called mass culture products, give evidence of how much the English society of the period was fascinated with the topic of prostitution. ${ }^{1}$

This article will focus on three of the abovementioned texts. One is The Crafty Whore, an anonymous dialogue between two courtesans that is framed between a preface that presents it as a cautionary text and an epilogue entitled "Dehortation from Lust," with an obvious moralistic purpose as well. Another text that will be studied is Richard Head's The Miss Display'd, a narrative in the picaresque mode to which the author adds a prefatory epistle of a similar cautionary nature, and the intrusive third-person narrator elaborates a discourse very critical of prostitutes and women in general. The third text that will be analysed is the anonymous The London Jilt, another picaresque novel, ${ }^{2}$ this time with an autodiegetic narrator who

* The author wishes to acknowledge funding from the Spanish government (MINECO project ref. FFI2015-68376-P), the Junta de Andalucía (project ref. P11-HUM-7761), and the Xunta de Galicia (Rede de Lingua e Literatura Inglesa e Identidade III, ref. ED431D2017/17). He also wishes to thank the British Library, Harvard U. Library, and ProQuest for granting permission to reproduce images.

${ }^{1}$ Examples of these texts are Select City Quaeries (1660), Strange and True Newes from Jacka-Newberries Six Windmills (1660), The Ladies Champion (1660), The Whores Petition to the London Prentices (1668), The Prentices Answer to the Whores Petition (1668), The Citizens Reply to the Whores Petition and Prentices Answer (1668), The Character of A Town Misse (1675), The Ape-Gentle-woman, or The Character of an Exchange-wench (1675), The Night-Walkers Declaration, Or, The Distressed Whores Advice to all their Sisters in City and Country (1676), Richard Ames's The Female Fire Ships. A Satyr Against Whoring (1691), John Dunton's The Night-Walker; Or, Evening Rambles in Search after Lewd Women (1696), and Edward Ward's The Insinuating Bawd and the Repenting Harlot (1699).

${ }^{2}$ Charles C. Mish describes The London Jilt as "probably the best piece of picaresque fiction of the time" (324). Charles Hinnant agrees that "it may very well be the finest (and by far the most entertaining) picaresque novel published in England in the late sixteenth and seventeenth centuries," and suggests it may have been a model for Defoe's Moll Flanders and Roxana (9). Gerd Bayer also states that it "clearly draws on picaresque elements and to some extent forms a Quixotic complement to the generic tradition of the rogue tale" (181). Roger Thompson prefers the label "rogue tale" to 
interlaces the relation with comments about social and moral issues, but whose paratextual material (title page and address "To the Reader") also presents the novel as a warning to male readers against the deceits and corruption of prostitutes. I will contend that, in those texts, female voice and agency are allowed but, at the same time, curbed by male authorial voices that allegedly attempt to warn against the crafty contrivances that prostitutes use in order to ensnare men, and thus reform the conduct of mainly the male readers. This declared moral purpose is stated mostly in paratexts and occasionally throughout the narratives, and accompanied with very crude, anti-female arguments and imagery that make these texts be imbued with and contribute to the pervasive misogynistic ideology of the time. These prostitute narratives are complex texts that work in several layers and deal with a thorny subject that provoked prurient voyeurism and moral condemnation, and that was also often recurrent in the political confrontation of the time.

\section{MISOGYNY AND PROSTITUTION IN RESTORATION ENGLAND}

David Gilmore has pointed out that misogyny is so widespread and pervasive in the world and throughout history that it must largely be psychogenic (xviii), a psychic attempt to diminish the importance of men's inner struggle in their relationship to women (9, see also Jack Holland, 5 and 272). The idea that women are inferior and dangerous to men thus may be seen as an unconscious rejection of men's desire for and dependence on women, a reflex of men's anxiety about women's equal or superior abilities, as well as a manner to justify and maintain women's lowly status in patriarchal society. Misogyny pervades widely in European philosophical, religious, cultural and literary traditions, from classical antiquity to the present day, presenting the entire female sex as the embodiment of everything that is offensive to the patriarchal order. Misogynistic approaches and comments in Aristotle and other Greek thinkers, Ovid and other Latin poets, the Bible and the doctrine of the Church Fathers, medieval literature and the so-called "querelle des femmes," Renaissance drama and the controversy generated around Joseph Swetnam's Arraignment of Lewde, Idle, Froward, and Unconstant Women (1615), all had established a robust tradition of anti-female thought that no doubt influenced English writers and readers of the Restoration period somehow. ${ }^{3}$ Playwrights drew profusely on Jacobean and Caroline drama, poets often imitated classical satire, puritan writers often quoted the Scriptures, and thus many of them rehashed old misogynous ideas and imagery, which were also present in conduct books, ballads, jests, and other cultural products of the late Stuart decades.

describe the genre of this narrative (290). For a study on how The London Jilt fits into the tradition of female picaresque, see Jorge Figueroa Dorrego (225-232).

3 See, for instance, the studies of Beverley Clack; Alcuin Blamires, Karen Pratt and C.W. Marx; Joan Kelly, and Linda Woodbridge. 
Many elements of the socio-political background of the Restoration period may have contributed to the generation of anxiety and feelings of insecurity in (at least part of the) society that found expression in misogynistic attitudes. The social and political implications of the Civil War, the puritan rule during the Interregnum, the unease caused by the visibility and supposed power of Charles II's mistresses, the libertine and cynical atmosphere generated, and the more noticeable presence of women in the public sphere (as political activists, preachers, actresses, and writers, for example) most likely produced feelings of anxiety in many men who may have deemed their identity, role, and privileges in the patriarchal society of the period questioned or threatened, and may have felt the need to reclaim or reinforce their dominance by disparaging the nature of women following the misogynistic tradition. Anti-female comments and attitudes pervade Restoration comedy (just remember William Wycherley's The Country Wife), but I would like to highlight here the satires on women that were written in the period. As Felicity Nussbaum has remarked, in these poems "women came to embody the very absence of patriarchal order and hierarchy that men must fear" (19), and the satirists rage at the female power to seduce and overcome men. In the anonymous Mysogynus: or, A Satyr Upon Women (1682), woman is described as an "imperfect thing" (3 and 5), loud, empty, soulless, and devilish, who is dominated by malice, envy, and hatred, and who degenerates man. Robert Gould's Love Given Over: or, A Satyr Against the Pride, Lust, and Inconstancy, Sc of Woman (1690) allegedly originated after the poet had been jilted by his beloved, and intends to "unmask" (7) female infidelity and warn other men to beware of women's "little Arts" (10), but also, as the subtitle says, of their lewdness ("if they durst, most Women would be Whores," 4) and pride ("the Deity they most adore," 5). In The Folly of Love. A New Satyr Against Woman (1693), Richard Ames sets out to "display" the female sex "[i]n their own colours" (5), and insists on describing women as deceitful, vain, lustful, and inconstant beings, whose only pleasure is to torment men and use them as simple toys or tools. Thus, the speaker of the poem concludes that the ideal world would be one without the presence and need of women. The misogyny of all these satires reveals men's fear of women's agency, autonomy, and consequent transgression of the established gender hierarchy.

As James G. Turner states, for early modern misogynists, the whore typified all women and, more particularly, all public women who did not comply with the domestic sphere or the passivity and moderated speech expected from them. She was, at the same time, an outcast and the image of worldliness, a criminal and a businesswoman, and provoked a mixture of indignation and attraction (10-11). Yet it was her rampant agency that seemed more worrying: "Every fornicatrix is assumed to be potentially a dominatrix, an Amazon, a virago" (22). The whore was a fascinating figure throughout the early modern period because it was one of the main stereotypes of the disorderly woman. Her unbridled sexuality was a challenge to patriarchal authority (being outside marital or parental control), and she lacked all the expected womanly qualities, such as chastity, fidelity, obedience, honesty, and maternal vocation (cf. Sara Mendelson and Patricia Crawford, 69-71). The whore was characterised instead by lust, deceit, vanity, unruliness, and an unorthodox approach to marriage and maternity (notice the coincidence of at least the first three vices to 
those ascribed to all women by misogynists). In the last decades of the seventeenth century, prostitution was seen as the result of individual moral failure, following the misogynistic belief that women were lewd by nature, as was explained before. So it was thought that prostitutes were motivated by an irrepressible, insatiable sexual desire. Yet they were also supposed to be moved by social ambition, greed, and a tendency to deceit, idleness and luxury, i.e. they were the very epitome of what characterised all women, according to contemporary misogynists. Thus whores were viewed as aggressors who lacked moral worth and deserved punishment. ${ }^{4}$ However, social attitudes towards prostitution were ambiguous because, as Robert Shoemaker has pointed out, it was condemned by moralists as a form of non-procreative, extramarital sex, yet other people considered it a necessary evil that served as an outlet to vent men's sexual drives and to keep other women unmolested. Prostitution was not itself illegal and, in the attempts to curb it for public order or health reasons, it was the prostitutes who were harassed, not their clients (Shoemaker 77). ${ }^{5}$

In early modern England professional prostitution was largely an urban activity, as in towns and, particularly, in London there were more potential customers and leisure facilities, and it was easier to go unnoticed (cf. Sharpe 158-169). As may be expected, women entered prostitution for economic reasons, usually after becoming orphaned and finding no other means of supporting themselves due to the scarce professional alternatives available for women (Shoemaker 76). Tim Hitchcock claims that, although brothels existed, most prostitutes worked for themselves, thus they had "a surprising degree of autonomy" (95). Hitchcock also states that most of them came from poor families and often interspersed periods of life in domestic service or other largely female occupations with sex services, mostly between the age of fifteen and twenty-five (96). Besides, Mendelson and Crawford report that women who made money through sexual services when young usually turned to procuring when older (295). Their life was not easy, because their activity had serious hazards such as venereal diseases, imprisonment, whipping and other forms of public punishment (296). We can add here that they were often victims of physical aggressions and rape, and had to deal with unwanted pregnancies alone.

Laura Rosenthal argues that prostitution exposed the contradiction of the emergent bourgeois culture, as it emblematised a disturbing intersection of the economic and the personal. In many representations, prostitutes consume in

4 This attitude gradually changed throughout the eighteenth century towards a view of prostitutes as "fallen" women who were victims of male seduction and financial difficulties, and therefore in need of certain degree of sympathy and aid. See, for instance, Hitchcock (99-100), Speck (127), and Rosenthal ("Introduction").

5 According to Melissa Mowry, anti-vagrancy laws were almost the only means the state had available for punishing prostitutes. They were convicted for being "lewd, idle, and disorderly women"; and they were sent to a house of correction to be whipped or put to labour (64). Local statutes forbid a woman from lying with more than one man in a given night, and a woman in a bawdy house was prosecutable for frequenting illegal establishments. Yet the actual exchange of sex for money was not illegal in England until the nineteenth century (106). 
excess and tempt men into irresponsible indulgences. Thus they serve as reminders of everything threatening about commerce. Restoration moralists and libertine writers generally present prostitutes as being driven by a desire for sexual pleasure, luxury, power, and wealth (see Infamous Commerce 4-18). Somewhere else, Rosenthal points out that libertine narratives of the Restoration and eighteenth century position themselves as warnings against the dangers of prostitution, but they tempt readers with stories of empowerment, luxury and social rebellion, suggesting that common women can rise to wealth and status through ambition and ruthlessness. Therefore, those narratives explore anxieties generated by the increasingly mobile world of the period ("Introduction" xx). From a more political perspective, Melissa Mowry adds that most of the satirical pornographies (in the etymological sense of descriptions of prostitutes) written in the Restoration period were part of the royalist and Tory propaganda because partisan authors related prostitution to republicanism and commerce, which were challenging the traditional class and gender hierarchies. Thus we can say that the figure of the prostitute acquires a metaphoric dimension, not only epitomising the disorderly woman and embodying unrestrained female sexuality, but also projecting the anxiety created by a new economic, political, and social order.

\section{THE CRAFTY WHORE}

The Crafty Whore is a free adaptation of the third dialogue in Aretino's Ragionamenti (1534-36), a work in which the protagonist, Nanna, tells a fellow prostitute her life as a whore. However, the English text does not mention this Italian origin, unlike other translations of Aretino's works, which were well known in seventeenth-century England. Regula Rohland de Langbehn suggests that The Crafty Whore may actually be an adaptation, either directly or through a French rendering, of the Spanish translation of that same dialogue by Fernán Juárez under the title of Coloquio de las damas (1548) (95). She bases her hypothesis on the similarity of the use of paratextual material that intends to present them as texts that warn young men against women's wiles. And we can add that both focus exclusively on the dialogue about Nanna's life as a prostitute, and ignore those about her life as a nun and as a wife.

The title page of The Crafty Whore (Figure 1) includes a subtitle and a short summary of the contents, specifying the purpose of the publication. The title itself emphasises the figure of the whore around which the dialogue centres and who is described as sly and guileful. The subtitle is "The Mystery and Iniquity of Bawdy Houses Laid Open," and this refers to the occult and sinful nature of the whore's actions that need to be exposed to the public in order to denounce them and warn readers against them. The title page also says that the text is written in the form of

a dialogue between two subtle Bawds, wherein, as in a mirrour, our City-Curtesans may see their soul-destroying Art, and Crafty devices, whereby they Insnare and beguile Youth, portraied to the life, by the Pensell of one of their late (but now 


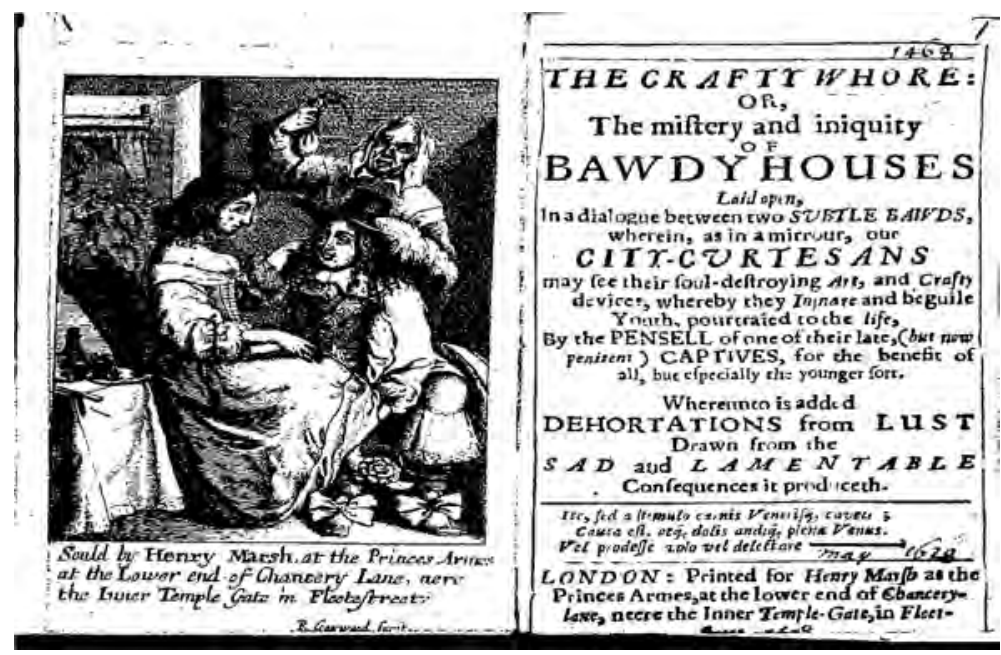

Figure 1. Frontispiece to The Crafty Whore (1658). (C) British Library Board. General Reference Collection, E.1927. (1). Image produced by ProQuest as part of EEBO and published with permission of ProQuest and the British Library.

Further reproduction is prohibited without permission.

penitent) Captives, for the benefit of all, but especially the young sort. Whereunto is added Dehortations from Lust Drawn from the Sad and Lamentable Consequences it produceth. (Title page)

Thus the text is presented as a kind of mirror that supposedly reflects real life, in this case, the vile and devious actions of the courtesans, who intend to cheat young men. The anonymous author claims to be one of those men who have been victims of those predatory women but that now he is repentant and writes for the benefit of young readers. The oxymoronic notion of penitent captive is paradigmatic of the discordant self-image that the misogynous customer of prostitution gives of himself as being both victim of deceit and culprit of lechery at the same time. $\mathrm{He}$ also announces that, in order to reinforce the moral message of the publication, there will be an epilogue dissuading readers from lust on account of its negative consequences. The frontispiece is also noteworthy, because it shows a young woman wearing a low décolleté that shows most of her breasts, a man whose sexual intentions are quite clear because he is slipping his hand under her skirt, and an old woman behind him with a bag of money. Therefore the illustration intends to point out the sexual and materialistic elements of prostitution.

In the preface, the author states that he wrote this text due to the large amount of prostitutes in England. He describes them as "Divells incarnate," "lascivium et dolosum pecus" (i.e. lustful and deceitful cattle), "unprofitable Drones" (i.e. parasites), and "sin selling Traders," who cheat men with their words, gestures, 
glances, etc. ${ }^{6}$ Using animal imagery again, he says he intends to teach the reader "to shun those Locusts, who still imploy their time in destroying the young plants of this land" (A2). He considers himself "a Beacon to forwarne you to beware how you come neare them" (A4), because he has often been "cheated in the rottenness and deceitfullnesse of these female commodities" (A6), but he is now reformed and wishes to be helpful to his countrymen. As can be noticed, the imagery used clearly dehumanises prostitutes, who are compared to animals or seen as commodities to be bought and disposed of by male customers, and even dangerous goods that are harmful to the users. Therefore, the author of this English version presents the whore story as a text of public interest that attempts to disclose and denounce the immoral, illegal activities involved in prostitution, and putting the blame entirely on the female side of the transaction.

The English author also alters the name of the main speaker, that changes from Nanna to Thais, as the famous Greek courtesan during the time of Alexander the Great, and this reinforces her identity as a whore. The text is a dialogue between her and Antonia, but it is Thais who dominates most of the narrative. The way she presents herself is not very different from the manner in which prostitutes are depicted in other male-authored texts of the time, either with male or female narrators. Although old at the time of the conversation, in her youth she was clever, beautiful, and only thought of achieving wealth and pleasure. She was tutored by her mother into prostitution at an early age, her mother acting as a bawd, assisting her in the search for customers, the use of cosmetics, the tricks to pretend virginity, and so on. The procedure with most customers is usually the same: she affects modesty and often nobility, cheats them and robs them. And, as most other prostitutes, when she grows older and her beauty diminishes, she becomes a bawd, deterministically doing the same function as her mother's.

Sometimes Thais generalises her traits as typical of all women. For example, she claims that no woman can be "satisfied with one Man" and that a man would have to be like Atlas and Hercules to content "the amorous emotions of a lustfull Woman" (39-40). She insists on this idea later when she asserts that "when the spur of lust Pricks us on to a false gallop, it requires a very lusty and experient rider to set us," and that she needs several horsemen (55). Thais also professes that she has cheated all her lovers because "the malice and hatred of a woman is implacable" (43), and that pleasure is a woman's chief happiness (53). This clearly concurs with the

${ }^{6}$ Similarly, the anonymous author of The Character of a Town Misse describes the protagonist as "a Caterpillar that destroys many a hopeful Young Gentleman in the Blossom" (4).

${ }^{7}$ Briget Orr contends that The Whore's Rhetorick contemplates a very sophisticated training for prostitutes, as they should be good orators, impersonators, readers, and merchants. They should be skilful in reading men and making men misread them (203-206). In The Practical Part of Love, the old bawd Ventricia provides young, newly-orphaned Helena with good clothes, and trains her in singing, dancing, and smiling alluringly. Yet Helena's main study is "to read men, i.e. glance in their faces and suck the Honey out of their pockets" (40). 
misogynistic discourse of other prostitute narratives, which used similar arguments. ${ }^{8}$ This seems to reveal the male authorship of the text behind this woman's words. Yet this is more noticeable when Antonia wonders what pleasure men can enjoy by having sex with someone "who hath lost the sence of feeling almost in that place, which should be more sensible, and which is worse (by using it so often) it becomes no better then a Jakes, for every rascall to disburthen himself therein" (82-83). A similar comparison of a prostitute's genitals to a toilet may be found in The London Jilt, as will be seen later.

Thais confesses that she follows Epicurus in thinking that pleasure is the "summum bonum" (53). . However, her approach to sex is normally cold, alienating and business-minded. From a very early age she sees sex as a source of income, has self-control and delays sexual satisfaction to tantalise her gallants and receive presents from them. As she puts it: "I was wiser at that time than the rest of our Sex, for I prefer profit before that momentary delight" (15). And, when she is having sex with a customer, "I hardly think on it, for my minde is either about some one of my friends, whom I must shortly cheat, and about himselfe in cunningly picking his pocket" (45). Other prostitute narratives of the period insist on this seamy alienation for the sake of financial profit. In The Whore's Rhetorick, for example, the bawd Madam Creswell teaches her young pupil Dorothea that

a Whore is a Whore, but a Whore is not a Woman; as being obliged to relinquish all those frailties that render the Sex weak and contemptible. A Whore ought not to think of her own pleasure, but how to gratifie her Bedfellow in his sensitive desires: She must mind her interest not her Sport; the Lovers sport, the ruine of his interest and the emptying his Purse. (144)

Rosenthal has pointed out that prostitution demands the female capacity to endure dispassionate sex, and this somehow contradicts the misogynistic view of women as lascivious creatures that prevailed in Restoration libertine texts. It was later in the eighteenth century when the prostitutes' alienation from their bodies and themselves was made more obvious (Infamous Commerce, 9). However, we can see that Restoration fictional whores such as Thais and Madam Creswell are aware of the need of such estrangement. As Thais herself says, "I ever prefer'd profit before

${ }^{8}$ One of the protagonists of The Practical Part of Love, Lucia, claims that all women are whores, some are "common whores" and most are "private ones," and that there are many cuckolds because women like variety (21). The anonymous author of The Character of a Town Misse says that she has a French servant who supplies her with dildos, and that with her gallant's money she maintains "two able Stallions (that she loves better than him) for performance of points wherein he is Defective" (7).

${ }^{9}$ Other protagonists of prostitute narratives of the Restoration period follow Epicurean hedonism. For example, in The Practical Part of Love, the narrator says that Lucia lived in "all manner of Ryot, and Epicurisme" (23), meaning that she used to wear good clothes, frequent pubs and the theatre, and have affairs with several men. As a consequence of such a luxurious life, she died of what the narrator calls "surfeit" when she was still young. 
pleasure, though I often joyn'd them together, otherwise poverty by this time had been my portion" (58).

Nevertheless, at the end of the story, the English male author chooses to bridle the voice and fate of the female characters in this dialogue by making them utter a sudden, hardly believable repentance, and by forcing both of them to determine to become hermits, which means a remarkable departure from the Italian original, where Antonia suggests Nanna's daughter should become a whore too. In the very same page and even paragraph in which Thais finishes telling a comic episode in which she has made a prank to a French gallant, she concludes that it may serve as a proof that such "pernitious and dissolute courses" only lead to "hell and damnation" (94); and consequently, "I am heartily sorry, that I have thus spent that time which should have been imployed and dedicated to divine worship, in Idlenesse, Wantonnesse, Riot, in perverting others, and in destroying my owne soule" (95). ${ }^{10}$ This is the blunt ending of the bawdy conversation between Thais and Antonia, which the English author inserts between the previously mentioned preface and a final "Dehortation from Lust." In this last section he says he hopes the dialogue will discourage the reader from lechery. He gives some advice on how to do so, such as avoiding idleness, intemperance, lascivious books, and bad companions, and adds some more examples of the bad consequences of lust. There is a remarkable inconsistency between the contents and tone of the dialogue on the one hand, and those of the paratextual material that frames it, on the other.

\section{THE MISS DISPLAY'D}

As regards the second text under scrutiny here, on the title page (Figure 2) we may read: "The Miss Display'd, with all Her Wheedling Arts and Circumventions. In which Historical Narration are detected, Her Selfish Contrivances, Modest Pretences, and Subtil Stratagems." So again the alleged purpose of the whore story is to expose the coaxing actions of prostitutes. The frontispiece this time shows some men and women on a kind of binge in what seems to be an inn or brothel, with an inscription saying: "Love not Lewd Women, for you'le find'em worse / Than all that's Bad, attended with a Curse." Hence, once more, the blame of prostitution is laid on women's lust rather than on men's. In "The Epistle to the Reader," Head describes a whore using nautical imagery, because she looks like a merchant ship that is

richly Laden, but by boarding, proves a Fire-ship that infallibly blows up, wherever she comes. Like a Watch from a Fire-ship she will turn her self to a Caterpillar, and destroys many a hopefull young Gentleman's Health and Estate in the Blossom; and when she turns Land-Syrene, she proves more dangerous than those in the

${ }^{10}$ Sarah Toulalan demonstrates the recurrent use of humour in pornographic texts of the seventeenth century. It is often a misogynistic, hostile, scatological, sexual humour, but in which it is also frequent to show men as cuckolds and butts of humiliating pranks (194-232). 


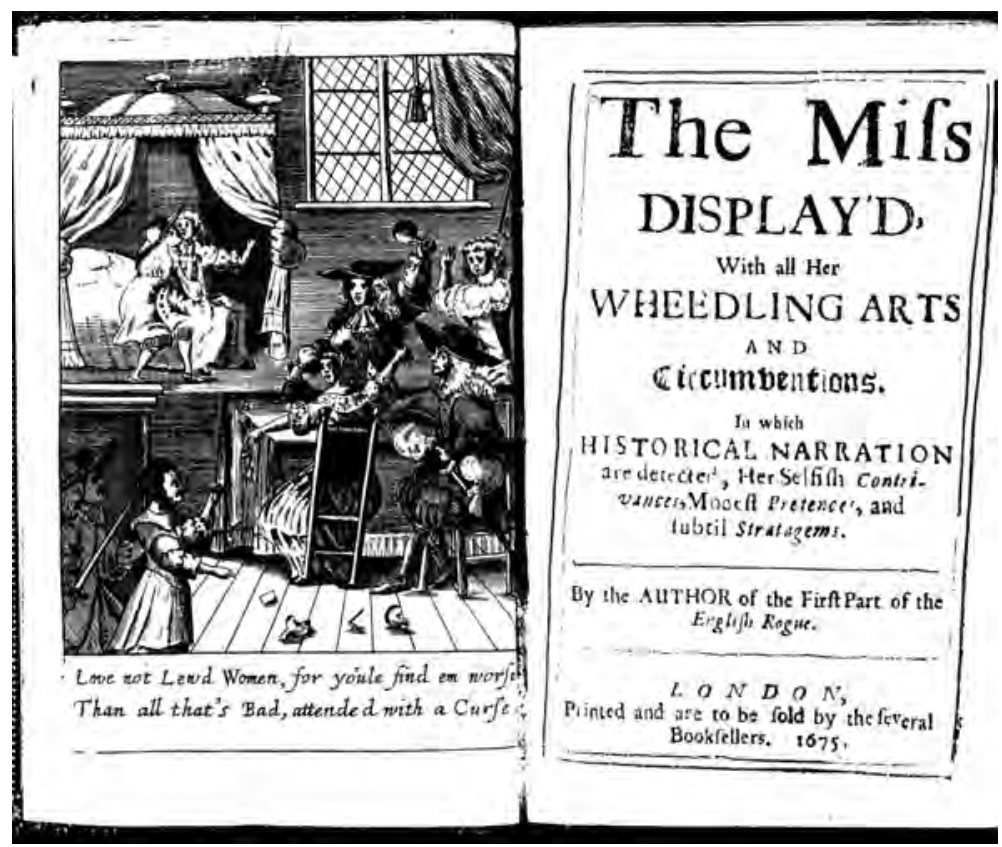

Figure 2. Frontispiece to Richard Head's The Miss Display'd (1675). Image produced by ProQuest as part of EEBO and published with permission of ProQuest, and Harvard U. Library. Further reproduction is prohibited without permission.

Ocean; for, he that falls into her hands runs a threefold hazard of Shipwracking, not onely his Fortune, but Soul and Body to boot. (A2)

The declared aim of this treatise is to deter the male reader "from ever having to do with these pernicious people, though seeming Angels of Light," and to advise honest women against debauchery, because if vice becomes "the Pilot of [their] fairly built and well-rigged Vessel," it will "infallibly run her upon the Quicksands of destruction" (A2). This shipwreck imagery is recurrent in contemporary writings about prostitution. ${ }^{11}$

11 The preface to The Practical Part of Love also includes similar nautical imagery when it comments that if the protagonist had "steer'd her Course by Virtues Compasse, she had never split her self against the Rock of Incontinence; Vice being the Pilot of this fairly built, and well rigg'd Ship, steer'd her a quite contrary Course to that of Virtue, and so in stead of bringing her Home to him that built her, ran her upon the quick-Sands of Destruction" (A6 $\left.6^{\mathrm{r}-\mathrm{v}}\right)$. Likewise, the anonymous writer of The Ape-Gentle-woman asserts about a prostitute that "both her habitation and her apparel like two friendly Sea marks, forewarn us of our Shipwracks if we sail in that Channel: But an Exchange 
At the beginning of the narrative, the ideas set forth in the paratextual material are reiterated: "This true History of a late famous or infamous Whore, laying open her cunning Contrivances, Intrigues, Cheats, Plots and Projects, either for pleasure or profit, is made publick to no other end then to the Reformation of Vice" (1). The narrator's aim is to encourage chastity, although in the story he will "strip the Courtezan out of all her Finery, leaving her nakedly to be exposed to the view of all, to the perpetual infamie of debauched Women" (1-2). This racy imagery of stripping the prostitute in order to expose not her naked body with an erotic purpose but her lust and guile with a moral aim is also recurrent in prostitute narratives. The title of this text already points at that direction with the word "Display'd."12 We have seen above how the title page of The Crafty Whore announces that it will reveal "The Mystery and Iniquity of Bawdy Houses." And, in the preface to The London Jilt, the author states: "For thou hast here, Reader, the Jilt displayed in her true Colours, all her Wheadling and Treacherous Decoys laid open" (41). This imagery intends to convey the declared aim of divulging, disclosing, and denouncing what is a somehow secret, clandestine activity -prostitution- for the supposed benefit of the readers. Yet Head emphasises the erotic dimension of the act of uncovering, undressing the body of the whore as well as unveiling, unmasking her debased actions. So it seems that he wishes to appeal to the voyeuristic urge of (at least part of) his readers. ${ }^{13}$

Head tries to distance himself from misogynists who state that "woman is an error, or imperfection in Nature" or that they are born for the affliction of men (4). Head claims that it is normally this kind of men who become involved in prostitution. He says they have "brutish appetites" and "are absolutely blind and irrational" (2). For him it is outrageous that, although they may have beautiful, prudent, loving wives, they "must ramble abroad, either invading other men's rights, or hazarding their healths amongst Prostitutes" (3); and they are usually critical of all women in general, paradoxically accusing them of lasciviousness. However, Head is not immune to misogyny, as we can see when he states that "doubtlessly there are good Women in the World, but they are so few, by reason of the spreading Contagion of their vicious inclinations" (4). Later in the narrative, he includes some comments that are reminiscent of similar remarks in misogynistic texts. For example, the narrator criticises the protagonist's proficiency in Latin and Greek by saying: "Surely, one tongue is enough for one Woman" (9), which obviously reminds us of

\footnotetext{
Wench like a fatal Rock hid under a mild superficies, Ruines a Man before he can say Lord have mercy upon us" (2). See also this imagery in The Character of a Town Misse (4) and in The London Jilt below.

12 Other examples can be found, for instance in Strange News from Bartholomew, where in the title page we read "The Wandring-Whore Discovered. Her Cabinet unlockt, her Secrets laid open, unvailed, and spread abroad." Later, the protagonist says: "I spread my shrouds, unveil my Cabinet, disclose my secrets, and open the pure Linnen Curtains that hang before my chief Fortress" (4).

13 For Toulalan, reading pornographic texts is an inherently voyeuristic or scopophilic act, and writing them involves a certain form of exhibitionism, as its purpose is revelation (185). Turner compares the "prurient-censorious compulsion" to witness the displaying of secret things in pornographic texts to that of many Londoners, such as Samuel Pepys, who went to see the spectacle of the bawdy-house riots in 1668 (174).
} 
the misogynistic critique of women's gossipy loquacity and inappropriate knowledge. Moreover, when the protagonist, Cornelia, laughs at her bawd falling down the stairs while escaping from a furious customer, the narrator comments: "See the vanity of the female Sex, their levity and mutability like a shower in April" (52), which joins the misogynistic belief in women's vain and volatile nature.

Cornelia, whose name is meaningful and recurrent in prostitute narratives (see, for instance, The London Jilt below), is characterised as other fictional whores of the period. She is a beautiful, witty, conceited, greedy, and ambitious woman. She is also unruly, "she would yield to no other power but her own, and acknowledge no God but her own Will and Pleasure" (8). Therefore, neither the submission nor self-denial expected in marriage or domestic service is attractive to her. She actually hates housework and living in the country, which she finds dull and vulgar, and that is the reason why she decides to leave her native Ulster and tries to find a more glamorous and lucrative life in Dublin and London. One of the first people she meets in Dublin is Ignatius, a witty, attractive gallant who tells her stories famous mistresses of popes and cardinals as examples of "how Persons of a low fortune have raised themselves to the height of wealth and honour, only by submitting to the humours of great men" (26). Cornelia is covetous, and likes treats, fine clothes, coaches and richly furnished lodgings, and she gets all this thanks to her affairs with several men, whom she deceives and robs. That is to say, she transgresses social expectations of class and gender, and this seems to be one of the main reasons why prostitutes are such fascinating figures at a period of incipient social changes in England such as the late seventeenth century.

Like other similar anti-heroines, Cornelia usually attracts gallants by pretending modesty and a higher social rank, and then robs them with the help of a bawd, here significantly called Polyandria. Both women engage in a strong relationship with ups and downs, and which is very successful financially speaking until the authorities arrest them and Polyandria is carted through the streets of Dublin, where she is thrown rotten eggs in public, a common punishment for prostitutes at the time. ${ }^{14}$ Cornelia then marries a wealthy dotard who soon dies and leaves her "a most triumphant, rich, eminent, Whore through the whole Kingdome" (116). ${ }^{15}$ She continues with her whorish activity and manages to get more money from her many gallants. The story ends with no real closure, we leave Cornelia in

${ }_{14}$ The characters of A Dialogue Between Mistris Macquerella, a Suburb Bawd, Ms Scolopendra, a Noted Courtezan, and Mr Pimpinello, an Usher complain about the consequences for them of the 1650 Act for suppressing the detestable sins of Incest, Adultery and Fornication. They comment that some prostitutes were being burned, carted, whipped or pilloried (3 and 5). And Strange Newes from Bartholomew-Fair ends with one of the prostitutes in this dialogue saying that, if her secrets are discovered, they will be whipped (6). Turner provides an interesting analysis of the use of violence and "ceremonies of abjection" against prostitutes and other transgressive women (24-42, and 47-73).

${ }_{15}$ This episode is actually very similar to that at the end of The Practical Part of Love. Helena marries an old dotard, whom she cuckolds and convinces to provide her with a considerable annuity and legacy. The old man dies heart-broken shortly afterwards and leaves Helena "a most triumphant rich now regnant Whore" (84). 
"a great height of unexpected Glory" (135), and not in old age but in the prime of her life. The narrator promises further adventures of this unrepentant, unpunished whore if he knows more about her; however, no sequel appears to have been ever published. There is no repentance, nor punishment, nor final explicit lesson. This open ending questions the moral purpose stated in the epistle to the reader, because Cornelia's career as a "miss" is certainly portrayed as reprehensible, but it proves to be profitable and is never chastised. For Raymond Gillespie, her story can be seen as a critique of the moral laxity in the Restoration period (219). He also argues that The Miss Display'd is a complex text that allows readers the thrill of the forbidden, with a voyeuristic glimpse of the obscure world of prostitution, and at the same time to condemn the licentious practices recounted, through Head's moralistic warnings (225).

\section{THE LONDON JILT}

As can be seen in Figure 3, the first edition of The London Jilt starts with a frontispiece that shows a woman (a bawd?) counting money, the devil behind her, a man embracing a woman in the background, and above all that an inscription saying "The Politick Whore," which is the subtitle of the novel. This suggests the materialistic, evil nature of the prostitute from the very beginning. Then the original title page says that the ensuing story shows "All the Artifices and Stratagems which the Ladies of Pleasure make use of for the Intreaguing and Decoying of Men." Thus the narrative is presented as a cautionary tale that exposes the schemes used by prostitutes to coax men. This admonitory nature of the narrative is reaffirmed in the address "To the Reader," where we are told that many dupes are deceived by prostitutes and thus ruin "their Health, their Fortune and Reputation," so "a Mirrour of [those women's] Damned Wheadling Arts and Cursed Devices" is necessary as a warning for men to learn how to avoid them (41). The narrative intends to dissuade men "from that Roving, Libertine, Lascivious Course of Life, and contribute but to the making Men be upon their Guard against all Female Ambuscadoes." The expected reader is therefore male and the story of the London Jilt is here presented as "beneficial in curbing the bad and unlawful Inclinations of Men." Consequently, this is a story of a woman supposedly told by herself, but addressed to men in an attempt to reform their conduct. The author does not intend to amend the prostitutes' life, probably because he does not believe they (as other women) are capable of moral reform, following the misogynistic ideology of the time.

This prefatory text includes the recurrent imagery of the beacon to warn about risky navigation and prevent shipwreck, ${ }^{16}$ and the aim of displaying the jilt's real nature and laying open her wheedling. Again we see the pseudo-vigilante and

16 The protagonist "is here set before thee as a Beacon to warn thee of the Shoales and Quick-Sands, on which thou wilt of necessity Shipwrack thy all, if thou blindly and wilfully continues 


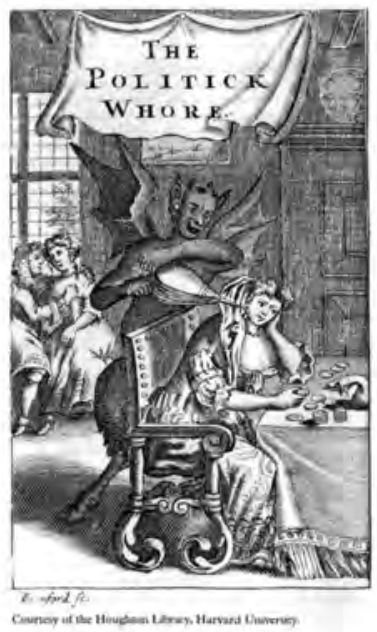

\begin{tabular}{|c|}
\hline $\begin{array}{c}\text { THE } \\
\text { LONDON } \nsucceq I L T:\end{array}$ \\
\hline OR, THE \\
\hline Politick Whore. \\
\hline $\begin{array}{l}\text { SHEW } 1 N G \text {, } \\
\text { All the Artifices and Stra- } \\
\text { tagems which the Ladies of Plea- } \\
\text { fure make ufe of for the In- } \\
\text { treaguing and Decoying of Men; } \\
\text { Interwoven with feveral Pleafant } \\
\text { Stories of the Miffes Ingenious } \\
\text { Performances. }\end{array}$ \\
\hline 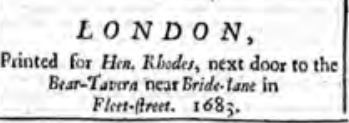 \\
\hline
\end{tabular}

Figure 3. Frontispiece to The London Jilt (1683). Image produced by ProQuest as part of EEBO and published with permission of ProQuest and Harvard U. Library.

Further reproduction is prohibited without permission.

pseudo-journalistic attempt of revealing the duplicitous nature of prostitutes and their clandestine activities as a form of public service. And, once more, we find the use of imagery that degrades the whore as grotesque monsters that embody corruption and disease. We are invited to see "our Jilt exposed naked in all her Deformities, that it may so create a horrour in thee" (42). Whores are here described as "rotten Bottoms," and "filthy, nasty, and stinking Carcasses" (41). This morbid degradation of the prostitute is reinforced when the author states: "A Whore is but a Close-stool to Man, or a Common-shoar that received all manner of Filth" (41), i.e. not just a corrupted body but a repository of communal, seminal waste. This sordid metaphor resembles that comparing a prostitute's genitalia to a "Jakes" in The Crafty Whore, and suggests a male authorship in both texts. ${ }^{17}$

After that prefatory paratextual material, the eponymous London Jilt tellingly starts her autodiegetic narrative mentioning the tradition of misogynistic literature: "There is no Nation in the World, but has in all Ages, furnished Authors,

and perseverest in steering that Course of Female Debauchery, which will inevitably prove at length thy utter Destruction" (41).

${ }^{17}$ It is also reminiscent of John Wilmot's final lines in his poem on Susan Willis, who was Thomas Colepeper's mistress: "Her belly is a bag of turds, / And her cunt a common shore" (200). 
who have made it their business to expose, as far as they are capable, the Frailties of the Female Sex" (43). She believes that the story of her life may be useful to warn men about women's deceitfulness. She, who is significantly called Cornelia like Head's "Miss," is the daughter of a London victualler who opens a tavern in Islington. ${ }^{18}$ As an only daughter, she has been brought up "in some sort of Libertinism" and provided with an education that included French and dancing, and was too expensive for her parents, but "it flattered their Ambition" (43). Thus her gender and class nonconformism is somehow the consequence of the excessive social aspirations of her middle class family. Cornelia has not been trained to be a conventional housewife or have an honest trade but as an idle gentlewoman with the typical social skills of the time. ${ }^{19}$ Her expected fate is frustrated at the early age of eleven when her father dies after being injured and robbed by a rope dancer. The subsequent financial straits force her mother to resort to prostitution for an income; but three years later the smallpox disfigures her mother's face and Cornelia must take over, and she seems to assume her new role without any hesitation or scruples. As happens to Helena in The Practical Part of Love and Thais in The Crafty Whore, Cornelia deterministically inherits prostitution from her mother. In his misogynistic satire against whoring, Richard Ames states that "She that's once a Whore, is always so" (17); and her daughter too, we may add, bearing in mind what prostitute narratives seem to suggest.

Cornelia often accuses herself and other women of lust, vanity, hypocrisy, anger, and revengefulness. Her stories will help young male readers learn "to expect from the Female Sex" (81), and not only from her or other prostitutes. As happens in other whore narratives studied here, women are shown as lewd. When Cornelia's mother has an affair with a bully after her face was marred by smallpox, the narrator comments that "it seems this Woman could not live without that Instrument" (a penis), and this proves the (unidentified) proverb: "If Lasciviousness renders Maidens mad, it makes Widdows Devils" (76). Cornelia herself acknowledges her sexual desire several times in the novel. For instance, when she has sex for the first time, she confesses that she found virginity burdensome and could not bear it any longer, but she is disappointed by her partner's poor performance (69-70). She warns her male readers that they should not expect to find love in a prostitute, "she either does it to get Money or to satisfy her Lascivious Temper" (117). Yet, in her case, money seems

18 According to Mowry, Islington was a traditional stronghold of political radicalism, and places such as taverns and inns often had dual functions as brothels and secret parliamentarian meeting places (46). There is no mention in the novel to any of those activities at Cornelia's father's inn while he lived, but Mowry's suggestion of his possible socio-political background is certainly interesting and worth taking into account.

${ }^{19}$ In The Night-Walkers Declaration, or, The Distressed Whores Advice to all their Sisters in City and Country (1676), the narrators claim that "The fond Indulgence of our too late repenting Parents contributed not a little to our destruction, bestowing upon us a Breeding and maintenance far above our birth or their abilities. The time we should have spent in learning Good-houswifery, was trifled away at the Dancing school, in French, Music, New wanton Songs, Plays, Balls, infecting Romances, etc." (4). 
to be her main motivation: "not a Man received the least Testimony of Affection from me, unless I was assured I should be paid for it with ready Money" (75).

Cornelia also says that hypocrisy is "an inseparable property of the Female Sex" (44), that women like being flattered: "Tell a Woman but once she's handsom, and the Devill will tell it to her a thousand times afterwards" (109), that they are proud and want to have better clothes and furniture than their neighbours (114), and that "the desire of revenge is inherent in women's nature from birth to death" (147). Therefore she reproduces much of the misogynistic discourse of the period. However, she claims not to be on men's side (94), and no enemy of women (155). She defends that whoring is due to an "abominable desire in the Hearts of Men" and that wives should be unfaithful to unfaithful husbands, "why should our Freedoms be less than that of the men, in what concerns the violation of the Conjugal Oath?" She argues that this double standard happens only because it is men, and not women, who make laws (120). And she thinks that the allegorical representation of Vice should be male rather than female, considering how vicious men are (142). Therefore Cornelia's discourse seems contradictory, combining misogynous comments with statements that are critical of men. Her story, at least read from a present-day perspective, seems to contravene the aims and the sordid descriptions of prostitutes set forth in the preface. Thompson contends that, apart from the stock moralising of the prefatory address to the reader and some comments at the ending, "the author's stance is completely amoral" (290). For Hinnant, it is difficult to establish a secure didactic message from this novel, due to the contrast between the harshly moralistic preface and Cornelia's witty, vital, and engaging narrative (33). She is not a flat, dull or repulsive character at all. Bayer points out that Cornelia claims agency and defends her decisions, is allowed to develop certain disagreements with the social environment in which she lives, and refuses to submit to the social stigma associated with female sexuality (184-185). And, for Mowry, she is "among the shrewdest characters early modern pornography created," because she is very entrepreneurial and learns to manipulate the conventions of the marketplace (119). Cornelia is a resolute, resourceful woman who manages to fend for herself in a hostile environment. She lives on hoaxing men, but none of those men is a model of virtue either; she usually acts in revenge of male violence, deceit, or arrogance, and benefits from men's folly and lust.

At the end, although she claims to repent and have no intention to corrupt others, Cornelia refuses to write a bigoted moral and even defends the human pursuit of pleasure:

I am not of the rank of those who after having led a vicious life during their Youth, and then becoming Converts, pretend to bygottism. [...] it seems rather a folly than a probity to forbid Men Joy and Mirth by sad and Melancholly Grimaces. It is a priviledge that we have, preferably to all other Creatures, and for that reason I have done it as often as things required, and I do not believe that I can desist from it tho' a number of curious Fools should tax me with being a Person of ill Conduct, until the Death has clos'd up my Mouth. (168) 
This is a rather unexpected ending for a narrative whose paratexts present as admonitory and morally beneficial. Cornelia's story, like that of Head's Cornelia or Helena's in The Practical Part of Love, ends without a clear, convincing repentance, and with no punishment. It is another example of the moral ambivalence of these prostitute narratives, which may be due to a conscious or unconscious combination of prurience and censoriousness on the part of the author, or his attempt to cater to different types of readers.

\section{CONCLUSION}

A combination of voyeurism and self-righteousness, of allure and abjection, may be found in these and other texts about prostitution that were published in the Restoration period, because they are often dressed up in moralistic attire, mostly in the paratextual material but also in several comments throughout the narrative. Yet intending to gaze at and expose the whore's clandestine, illicit affairs also involves a certain scopophilia. In generic terms, these texts are multilayered, combining cautionary, condemnatory, picaresque, bawdy, and comic elements, in an attempt to legitimise the obscene content, offer variety, and appeal to different readers. In gender terms, the surreptitious, sexual activities of these "ladies of pleasure" are often presented from a sexist perspective that mainly blames them rather than their customers. In these narratives, prostitutes are given the limelight, agency, voice, and even success, but they are also denigrated, commodified, portrayed as filthy, devilish beings, and as unruly subjects that challenge social and gender order.

The present article has focused on three Restoration narrative texts about whores -namely The Crafty Whore, The Miss Display'd and The London Jilt-in which the voice of the female protagonists has somehow been suppressed or monitored by the male authorial voice, whose alleged aim is to lay open and display the crafty contrivances of prostitutes. This authorial voice often generalises the whores' traits as typical of all women, as if they epitomised the real essence of women, and adopts the misogynistic discourse that prevailed in Restoration prose fiction, satirical poetry, and drama. This discourse accuses women of lust, pride, inconstancy, deceit, and malice. Even similar imagery is used, comparing whores to devils, animals, commodities, and even latrines, and the damage caused by prostitution to a disastrous shipwreck. However, the moralistic, cautionary purpose declared in the paratexts is not as consistent as may be expected, because at the end of the narratives the protagonists do not express repentance or do so bluntly, briefly and unconvincingly, and they suffer no punishment whatsoever in the sense of being carted, pilloried, whipped, imprisoned, or contracting a venereal disease, as usually happened to actual prostitutes in Restoration England. In The Crafty Whore, Thais and Antonia suddenly decide to become hermits, however the (anti-)heroines of The Miss Display'd and The London Jilt not only manage to fend for themselves in a hostile environment, but even become rich and "triumphant." There is no moral closure in Head's novel, and there is an ambiguous combination of repentance and defence of hedonism at the end of The London Jilt, instead of a clear moral or the 
strict application of poetic justice in texts that purport to be admonitory and didactic. The prostitutes of the three texts analysed here are resolute, resourceful, independent women whose empowerment and rise to wealth and status with dishonourable means implied a challenge to the traditional social order. Thus prostitution may be working as a metaphor of the increasing materialism and social mobility in English society. Yet it may also be related to political confrontation (since prostitution in Restoration libertine texts is frequently connected to republicanism or Whiggism), and to the prevailing gender tensions as well, because these texts are, as we have seen here, often impregnated with a crude misogynistic ideology.

Reviews sent to author: 25 June 2019

Revised paper accepted for publication: 23 July 2019 


\section{WORKS CITED}

Ames, Richard. The Female Fire-Ships. A Satyr against Whoring. E. Richardson, 1691.

Ames, Richard. The Folly of Love. A New Satyr against Woman. E. Hawkins, 1693.

The Ape-Gentle-woman, or The Character of and Exchange-wench. Francis Pye, 1975.

Bayer, Gerd. Novel Horizons. The Genre Making of Restoration Fiction. Manchester UP, 2016.

Blamires, Alcuin, Karen Pratt and C.W. Marx, eds. Woman Defamed and Woman Defended. An Anthology of Medieval Texts. Clarendon, 1992.

The Character of a Town Misse. W.L., 1675.

Clack, Beverly, ed. Misogyny in the Western Philosophical Tradition. Routledge, 1999.

The Crafty Whore: Or, The Mystery and Iniquity of Bawdy Houses Laid Open. Henry Marsh, 1658.

A Dialogue between Mistris Macquerella, a Suburb Bawd, Ms Scolopendra, a Noted Courtezan, and Mr Pimpinello, an Usher. Edward Crouch, 1650.

Figueroa Dorrego, Jorge. "Transgression Class, Gender, and Genre. The Jilt Narratives of Restoration England." Genre in English Literature, 1650-1700. Transitions in Drama and Fiction. Ed. Pilar Cuder Domínguez. Cambria, 2024. 221-254.

Gillespie, Raymond. "Richard Head's The Miss Display'd and Irish Restoration Society." Irish University Review 34. 2 (2004): 213-228.

Gilmore, David, Misogyny. The Male Malady. U of Pennsylvania P, 2001.

Gould, Robert. Love Given Over: or, A Satyr against the Pride, Lust, and Inconstancy, \&o of Woman. R. Bentley and J. Tonson, 1690.

Head, Richard. The Miss Display'd with All Her Wheedling Arts and Circumventions. N.p., 1675.

Hinnant, Charles. Introduction. The London Jilt. Ed. C. Hinnant. Broadview, 2007. 9-35.

Нıтснсоск, Tim. English Sexualities, 1700-1800. Macmillan, 1997.

Holland, Jack. A Brief History of Misogyny. The World's Oldest Prejudice. Robinson, 2006.

Kelly, Joan. "Early Feminist Theory and the 'Querelle des Femmes,' 1400-1789." Signs, 8.1 (1982): 4-28.

The London Jilt. Ed. C. Hinnant. Broadview, 2007.

Mendelson, Sara and Patricia Crawford. Women in Early Modern England. Oxford UP, 1998.

Mish, Charles. "English Short Fiction in the Seventeenth Century." Studies in Short Fiction 4 (1969): 233-330.

Mowry, Melissa. The Bawdy Politic in Stuart England, 1660-1714. Political Pornography and Prostitution. Ashgate, 2004.

Mysogynus: or, A Satyre upon Women. John Langly, 1682.

The Night-Walkers Declaration, or, The Distressed Whores Advice to All Their Sisters in City and Country. D.M., 1676.

Nussbaum, Felicity. The Brink of All We Hate. English Satire on Women, 1660-1750. UP of Kentucky, 1984. 
OrR, Briget, "Whores' Rhetoric and the Maps of Love: Constructing the Feminine in Restoration Erotica." Women, Texts and Histories, 1575-1760. Ed. Clare Brant and Diane Purkiss. Routledge, 1992. 195-216.

The Practical Part of Love. N.p., 1660.

Rohland de Langbehn, Regula. A dos luces. El feminismo de la picaresca femenina hasta Defoe. Juan de la Cuesta, 2012.

Rosenthal, Laura J. Infamous Commerce. Prostitution in Eighteenth-Century British Literature and Culture. Cornell UP, 2006.

Rosenthal, Laura J. Introduction. Nightwalkers. Prostitute Narratives from the Eighteenth Century. Ed. L. Rosenthal. Broadview, 2008. IX-Xxix.

Sharpe, James A. Crime in Early Modern England, 1550-1750. 2nd ed. Longman, 1999.

Shoemaker, Robert B. Gender in English Society, 1650-1850. The Emergence of Separate Spheres. Longman, 1998.

Speck, W.A. "The Harlot's Progress in Eighteenth-Century England." The British Journal for Eighteenth-Century Studies 3.2 (1980): 127-139.

Strange Newes from Bartholomew-Fair, or, The Wandring-Whore Discovered. Theodorus Microcosmus, 1661.

Thompson, Roger. “The London Jilt." Harvard Library Bulletin 23.3 (1975): 289-294.

Toulalan, Sarah. Imagining Sex. Pornography and Bodies in Seventeenth-Century England. Oxford UP, 2007.

Turner, James G. Libertines and Radicals in Early Modern London. Sexuality, Politics and Literary Culture, 1630-1685. Cambridge UP, 2002.

The Whores Rhetorick, Calculated to the Meridian of London; And Conformed to the Rules of Art. George Shell, 1683.

Wilmot, John, Earl of Rochester. The Complete Works. Ed. Frank H. Ellis. Penguin, 1994.

Woodbridge, Linda. Women and the English Renaissance. Literature and the Nature of Womankind, 1540-1620. U of Illinois P, 1986. 
